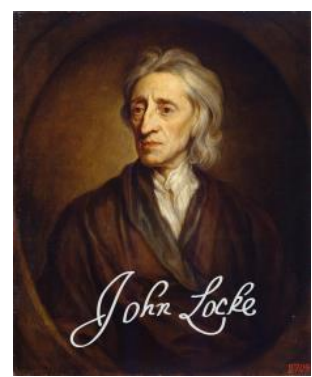

LOCKE STUDIES

Vol. 14

https://doi.org/10.5206/ls.2014.723 | ISSN: 1476-0290

Originally published: 2014

Published online: 19 FEBRUARY 2018

(C) Locke Studies, 2014

\title{
Locke and the Power to Suspend Desire
}

\author{
JULIE WALSH (UNIVERSITÉ DU QUÉBEC À MONTRÉAL)
}

Recommended citation:

Walsh, Julie. "Locke and the Power to Suspend Desire." Locke Studies 14 (2014): 121-157.

https://doi.org/10.5206/ls.2014.723

For more information about this article:

https://ojs.lib.uwo.ca/index.php/locke/article/view/723

Locke Studies is published by The John Locke Society.

This is an open access article published under the terms of the Creative Commons Attribution-

NonCommercial-ShareAlike 4.0 International license, which permits use, distribution and reproduction in any medium, provided the original work is properly cited and shared under the original license. 


\title{
LOCKE AND THE POWER TO SUSPEND DESIRE
}

\author{
JULIE WALSH
}

The chapter of Locke's An Essay Concerning Human Understanding (hereafter Essay) entitled 'Of Power' is notoriously difficult to interpret. It is long, complicated, went through a substantive overhaul in advance of the second edition of the Essay, and was even further amended for the fourth and fifth editions. One of the questions about 'Of Power' that has vexed commentators is whether the notion of a power to suspend desire, added in the second edition, indicates that Locke thinks that some events are not determined by antecedent causal factors, namely, the activity of the power to suspend. One of Locke's correspondents, Philippus van Limborch, thought that it did, and pressed Locke on this point in a series of letters from 1701-2. Vere Chappell has stated that certain comments, in particular of the fifth edition, strongly suggest that Locke takes the act of suspending desire to be caused by an undetermined volition. ${ }^{1}$ On this view, when we suspend our desire for a particular object the volition to do so occurs without being determined by any antecedent causal factor.

While the power to suspend does seem to suggest a kind of prima facie undetermined activity, there are nevertheless many indications throughout the chapter where Locke gives just the opposite impression - that no volition occurs without being motivated by uneasiness caused by the search for pleasure or the avoidance of pain. These passages make it seem that all volitions, including the ones that lead to suspensions of desire, are determined. They require both an object and a motivation, the

1 Vere Chappell, 'Locke on the Liberty of the Will', in Locke's Philosophy: Content and Context, ed. G.A.J. Rogers (Oxford, 1994), 101-21, 118-21. In the end, Chappell remains agnostic about whether Locke holds that suspension is the result of an undetermined power. He affirms only he cannot rule this position out. (A similar agnosticism is present in his paper 'Locke on the Suspension of Desire', The Locke Newsletter 29 (1998): 23-38). I argue here that it must be ruled out. 
desire to eliminate uneasiness, to pursue the object. The tension between volitional determinism and suspension of desire is generated when we wonder, as Limborch did, how we are able to suspend our volitions if they are always determined by antecedent causes? In order to give suspension the kind of power that it seems to need-the power to interrupt a desire that would otherwise be determining - it seems that suspension needs to be the kind of event that is caused by an undetermined volition. That this is Locke's view is far from clear. But if suspensions are not caused by undetermined volitions, what are they? In order to answer this question we must pay close attention to what Locke actually says about suspension.

My aim in this paper is to determine how Locke understands suspension and the role it plays in his view of human liberty. To this end I (1) discuss the deficiencies of the first edition version of 'Of Power' and why Locke needed to include the ability to suspend in the second edition, then (2) analyze Locke's definitions of the power to suspend with a focus on his use of the terms 'source', 'hinge', and 'inlet' to describe the power. I determine from these descriptions that the ability to suspend is a passive power and is a necessary condition for the rational deliberation that Locke takes to be necessary for acting as a free agent. In (3) I connect Locke's view of the power to suspend to his discussion in the sections that precede 'Of Power'. I argue that the kind of judgement that Locke endorses in his discussion of the Molyneux problem is also at work in acts of suspension. In (4) I apply my interpretation to Locke's description of the connection between the power to suspend and liberty. In (5) I conclude with a discussion of a passage from the fifth edition of the Essay. Locke adds this passage to address worries raised by Limborch over the course of their correspondence. According to Chappell, it lends support to the view that Locke takes suspensions to be caused by undetermined volitions.

\section{The Need For Suspension}

Locke begins 'Of Power' by stating that while examples of passive 
powers abound in everyday life 'by almost all sorts of sensible things', the only way to get the idea of an active power is by reflecting on the operations of the mind. By reflecting on mental operations we acquire the ideas of thinking and motion and, in particular, a special kind of motion that is self-initiated. Self-initiation is what Locke takes to be characteristic of an active power: it allows for the 'beginning of Motion'. ${ }^{2}$ For example, while the change of place of a billiard ball involves movement, it is only passive movement. The ball does not move itself, but is moved by something else. By contrast, when a person moves from one room to another, we infer that she has initiated that movement. She is not moved, but rather moves herself. This inference is derived from our own reflection on the operation of our mind. We know by experience that a thought of our mind can effect a change in our body. The idea of power that we obtain upon this reflection is to begin or forbear, continue or end several actions of our minds, and motions of our Bodies, barely by a thought or preference of the mind ordering, or as it were commanding the doing or not doing such or such a particular action'.

Locke states that this power enables the mind to take up the consideration of any idea and to move or rest the body according to preference. He names this power the will and calls its exercise willing or volition. ${ }^{4}$ In order for a volition to occur, the will must be accompanied by the power of the understanding. The understanding is the passive power that allows for the perception of ideas, the signification of signs, and the perception of the agreement and disagreement of ideas. ${ }^{5}$ The understanding perceives and when the will prefers one perception to another it has

2 John Locke, An Essay concerning Human Understanding, ed. P. H. Nidditch (Oxford, 1975), II. xxi. 4, 234-35.

3 Essay, II. xxi. 5, 236.

4 Ibid.

5 Ibid. 
a volition that initiates the necessary action to pursue its preference. Locke defines liberty as 'the Idea of a Power in any Agent to do or forbear any particular Action, according to the determination or thought of the mind, whereby either of them is preferr' $d$ to the other'. 6

So, when we act or forbear action, there is a motivating reason behind our behaviour. In the first edition of the Essay, Locke states that the motive for action is preference. ${ }^{7}$ Volitions are determined by what is more pleasing, and those things that are pleasing are deemed good. ${ }^{8}$ Good objects arouse feelings of pleasure within us and those feelings motivate us to act. Locke concludes that it is the greater good that determines the will. ${ }^{9}$ This is a statement of his volitional determinism-volitions require an object and a motivation for pursuit (pleasure) or avoidance (pain).

But there is a problem with this account. While we may see that a greater good exists, this does not entail that it pleases us more than a good that is known to be lesser. Locke's first edition account leaves no opportunity to turn away from a desired present good in favour of pursuing a remote good. While we might see that a greater good exists, if it pleases us less, we will not pursue it. This is the classic problem of weakness of will and Locke acknowledges it in the course of offering his revised view in the second edition. ${ }^{10}$ He begins by saying that it is not, in fact, the greatest perceived good that determines the will, but the greatest felt good. Locke says:

6 Essay, II. xxi. 8, 237.

7 Essay, II. xxi. 28, 248, first edition.

8 Essay, II. xxi. 29, 248, first edition.

9 Essay, II. xxi. 29, 251, first edition.

10 William Molyneux likely prompts this revision. See William Molyneux to Locke, 22 December 1692, in The Correspondence of John Locke, ed. E.S. de Beer (8 vols., Oxford, 1976-), iv, 599-602. 
[U]pon a stricter enquiry, I am forced to conclude, that good, the greater good, though apprehended and acknowledged to be so, does not determine the will, until our desire, raised proportionably to it, makes us uneasy in the want of it...let a Drunkard see, that his Health decays, his Estate wastes...' $[t]$ is not for want of viewing the greater good: for he sees it, and acknowledges it...but when the uneasiness to miss his accustomed delight returns, the greater good loses its hold, and the present uneasiness determines the will to the accustomed action. ${ }^{11}$

The drunkard perceives the greater goods of health, wealth and honour, and he affirms them. But his greatest uneasiness is for his 'accustomed delight' and that uneasiness overrides all other intentions or perceptions. Only when his uneasiness is raised in want of the greater good over and above the uneasiness for drink will his volitions be determined by his desire for more virtuous things. ${ }^{12}$

While the replacement of 'greatest good' by 'uneasiness in want of a perceived good' as the motive for volition better corresponds to the felt experience of pursuing a known lesser good, the account is still incomplete. For Locke has not replaced his first edition account with an account that appeals to weakness of will as an explanation for action that is not in line with knowledge. Instead, he has located the cause of bad behaviour in a lack of an uneasiness that corresponds to our knowledge of the good. And while he suggests that we may raise our desire 'proportionably to' our knowledge of the greater good, he does not say how. He begins to

\section{1}

Essay, II. xxi. 35, 253-54, editions 2-5.

12

While Locke distinguishes between 'desire' and 'uneasiness' in $\S \S 31-32$, the precise difference between the terms is not obvious and he seems to use them interchangeably throughout chapter xxi. One chapter earlier, though, he states that 'The uneasiness a Man finds in himself upon the absence of any thing, whose present Enjoyment carries the Idea of Delight with it, is that we call Desire, which is greater or less, as that uneasiness is more or less vehement' (II. xx. 6, 230). One way to read this is that 'uneasiness' is the term for the general category of the phenomenal experience of disquiet of the mind whereas 'desire' is the more precise term that targets the object, the possession of which is thought to be able to soothe the disquiet. This interpretation seems to be borne out by the discussion of II. xx. 7-15, 231-32. 
fill in the account, however, with the introduction of the power to suspend desire. Locke acknowledges that there are always a great many uneasinesses pressing upon us and that, for the most part, the greatest one determines the will. But not always. For, 'the mind having in most cases, as is evident in Experience, a power to suspend the execution and satisfaction of any of its desires, and so all, one after another, is at liberty to consider the objects of them; examine them on all sides, and weigh them with others' ${ }^{13}$ The mechanism seems to be:

(1) We consider a present good.

(2) If we are not sure that the present good is a true good we suspend our desire of it.

(3) While our desire is suspended we have the occasion to examine the good.

(4) If we determine that the good under examination ought to be sacrificed for the sake of the pursuit of a remote good, our uneasiness for it diminishes.

(5) Our volition will not be determined by that present good but by some other uneasiness that comes to be determining in the absence of the desire of the present good. ${ }^{14}$

It might seem odd that Locke takes a cognitive processexamination - to be able to alter uneasiness. This highlights his high estimation of the power of the mind. With reasoning, desires can be changed to accurately reflect the true relative goodness of objects. He does not say more about how this happens, just that

\footnotetext{
13 Essay, II. xxi. 47, 263, editions 2-5.

14 Essay, II. xxi. 46: 262, editions 2-5.
} 
with appropriate consideration and examination it is in our power to make it so. ${ }^{15}$

While suspension answers the question of how we can escape determination by our strongest present uneasiness, Locke has merely pushed the problem back one step. For now he must explain how and why we come to suspend. If volition causes suspension, then uneasiness would have to motivate suspension, for Locke gives no indication that suspension is a special kind of event with a unique motivation. If uneasiness is the motive for suspension, then we must wonder how we could raise our uneasiness for suspending a desire without first suspending our desire for things to which we are naturally attracted. ${ }^{16}$

Locke's discussion of suspension is brief. It is mostly confined to the chapter 'Of Power' and even there is mentioned only a handful of times. ${ }^{17} \mathrm{He}$ does not explicitly tell us whether it is an active or passive power. ${ }^{18}$ He does, however, use three other terms to describe it: 'source', 'hinge', and 'inlet' of liberty. These descriptions make it clear that the power to suspend is not identical to liberty and that it is a necessary condition for liberty. Beyond this, it is not obvious how to interpret Locke's use of these terms. But we can gain some insight into what he means by looking at other places in the Essay where the same analogies are used. What we see is that these terms are used exclusively to describe passive powers. Recognizing that suspension is one such passive power brings Locke's definition of liberty into sharp focus-action

15

Essay, II. xxi. 45-46:260-62, editions 2-5.

16 On this point I agree with Richard Glauser. See his 'Liberté, compatibilisme et agnosticisme chez Locke', Revue Philosophique de Louvain 107, (2009): 675-97, at 681.

17 The only other mentions come in the chapter 'Wrong Assent, or Errour'. See Essay IV. xx. 7, 711; IV. xx. 12, 715; IV. xx. 15, 717.

18 Essay, II. xxi. 47, 263, editions 2-5; II. xxi. 50, 266, editions 2-5; II. xxi. 56, 271, fifth edition; IV. xx. 12, 715, editions 2-5; IV. xx. 15, 716-17, editions 2-5. 
informed by rational deliberation. ${ }^{19}$

\section{Source, Hinge, and Inlet}

The first time the ability to suspend is mentioned in the Essay in 'Of Power' $\$ 47$, it is characterized as the source of liberty:

To prevent this [the determination of the will prior to examination] we have a power to suspend the prosecution of this or that desire... [t]his seems to me the source of all liberty. ${ }^{20}$

Locke says that to prevent error, we have the power to suspend. And this power is the source of all liberty. It is not obvious what to make of this description. While it might be natural to think that 'source' implies 'cause' I do not take this to be Locke's intended meaning. Both suspension and liberty are characterized by Locke as powers and powers belong only to agents. ${ }^{21}$ Locke goes to great lengths to illustrate how absurd and confused it is to attribute one power to another (as we do when we ask whether the will is free, for both willing and freedom are powers belonging to human beings) or when we say that two powers can act on each other (as we do when we wonder whether the understanding acts on the will or vice versa). The power to do one action, he says, 'is not operated on by the power of doing another Action'. ${ }^{22}$ So it is not right to think of the power to suspend as the cause of the power of liberty.

19 The question of whether the power to suspend is active or passive has not been engaged in the secondary literature. Commentators simply assume that the power is active. Recognizing its passivity affords a clearer picture of Locke's overall view. This picture is similar to the one Gideon Yaffe expounds in Liberty Worth the Name: Locke on Free Agency (Princeton and Oxford, 2000), but motivated in a very different way. While Yaffe only briefly engages the question of the nature of suspension (148, n. 31), my interpretation is grounded on an analysis of what (little) Locke says about its nature.

20

Essay, II. xxi. 47, 263, editions 2-5 (emphasis added).

21

Essay, II. xxi.16, 241.

22

Essay, II. xxi.18, 242. 
In order to see what Locke might mean by using 'source' to describe the power to suspend in this way, we can look to other uses of the term 'source' in the Essay for more information about what Locke intends by the word.

When Locke describes something as a source, he is almost always talking about sensation and reflection. He says that sensation and reflection are the two sources of knowledge. ${ }^{23}$ Notice that the things characterized as sources are passive powers-sensation and reflection. They are not the causes of knowledge, but rather passively allow for knowledge. ${ }^{24}$ They are necessary elements in the mechanism that has knowledge as its end result. But these powers cannot trigger the mechanism without some antecedent stimulus. If Locke's use of source is consistent, we might think that when he says that the power to suspend is the source of liberty, he means that suspension is a necessary element in the process that results in free action or liberty. On this interpretation, the power to suspend allows for free action in the same way that sensation and reflection allow for knowledge. As we will see, Locke's other descriptions of this power confirm this interpretation.

Before moving to Locke's other descriptions of the power to suspend, two further texts must be mentioned here. In Book IV of the Essay, Locke states that

23

Essay, II. i. 3, 105; II. xi. 14, 162; II. xii. 2, 164; II. xiv. 2, 181; II. xxiii. 29, 312. The other uses of 'source' are as follows: Locke also says that sensible ideas are the sources of ideas that 'stand for Things that fall not under our Senses' (III. i. 5, 403); he denies that a complex idea is the source or the real essence of that which a complex idea represents (III. vi. 3, 439-40); he asserts that the sun is the source of heat (IV. vi. 11, 586); he denies that maxims or principles are the sources of knowledge (IV. vii. 2, 600). These uses uphold the interpretation that 'source' is to be understood as a necessary condition, but not an active cause.

24 See also Essay, II.xi.17:162. Locke does, however, state that in bare naked Perception, the Mind is, for the most part, only passive; and what it perceives, it cannot avoid perceiving' (II. ix. 1, 143). What Locke might mean here by 'for the most part only passive' is not obvious. It is possible he means that where we turn our attention is in some sense under our control (see IV. xiii. 1, 650). But see also II. xxi. 72, 286, editions 2-5, where he states that perception or the power of thinking is 'but a Passive Power'. 
It is evident, that what had its Being and Beginning from another, must also have all that which is in, and belongs to its Being from another too. All the Powers it has, must be owing to, and received from the same Source. This eternal Source then of all being must also be the Source and Original of all Power; and so this eternal Being must be also the most powerful. ${ }^{25}$

And in the same vein, in the third letter to Stillingfleet:

Perception and knowledge in that one eternal being, where it has its source, it is visible, must be essentially inseparable from it; therefore the actual want of perception in so great part of the particular parcels of matter, is a demonstration, that the first being, from whom perception and knowledge is inseparable, is not matter. ${ }^{26}$

These passages quite plainly state that God is the source of power. According to my interpretation, Locke's use of 'source' does not imply a power with causal activity, but rather a necessary but passive element in a process. My interpretation applied here, then, would lead to the undesirable suggestion that God, as the source of perception, is passive. But notice that these two passages treat a topic that is quite distinct from the discussion of the relation between the power to suspend and liberty: the very source of powers themselves. While Locke states that God is the source of power and is, of course, active, this does not block the possibility that finite powers themselves are a different, passive kind of source. So while the source and creator of all power is active, that created powers like perception and suspension themselves might

25 Essay, IV. x. 4, 620 (emphasis added).

26 John Locke, 'Mr. Locke's Reply to the Bishop of Worcester's Answer to his second Letter', in The Works of John Locke (10 vols., London, 1823), iv, 468-69 (emphasis added). Here Locke is trying to block Stillingfleet's assumption that 'want of perception' being an essential property of matter entails that God, a being that perceives, must be immaterial. For an overview of the details of the Locke-Stillingfleet debate, see Paul Helm 'Locke on Faith and Knowledge', The Philosophical Quarterly 23, (1973), 52-66. I thank an anonymous referee for this journal for drawing my attention to this potentially recalcitrant passage. 
be passive is not ruled out. ${ }^{27}$

In $\S 51$, Locke states that 'the highest perfection of intellectual nature, lies in a careful and constant pursuit of true and solid happiness' and that in service of this goal we must be careful to avoid mistaking certain present goods for goods that will lead to 'true and solid happiness'. To do so we are 'obliged to suspend the satisfaction of our desire in particular cases' until 'we are as much inform'd upon this enquiry' as possible. Then in $\S 52$ he says:

This is the hinge on which turns the liberty of intellectual Beings in their constant endeavours after, and a steady prosecution of true felicity, that they can suspend this prosecution in particular cases till they have looked before them, and informed themselves, whether that particular thing, which is then proposed, or desired, lie in the way to their main end, and make a real part of that which is their greatest good. ${ }^{28}$

There is only one other place in the Essay where Locke uses the term 'hinge' and he uses it in a similar turn of phrase:

Pleasure and Pain, and that which causes them, Good and Evil, are the hinges on which our Passions turn: and if we reflect on our selves, and observe how these, under various Considerations, operate in us; what Modifications or Tempers of Mind, what Internal Sensations, (if I may so call them,) they produce in us, we may thence form to our selves the Ideas of our Passions. ${ }^{29}$

The use of 'hinge' in the passage about the passions is straightforward. Without pleasure or pain there would be no passions. When we reflect on our experience of pain or pleasure we acquire the ideas of the passions. These ideas then become

27 Locke is explicit that he is not interested in investigating the origins of power in chapter xxi (see §2).

28 Essay, II. xxi. 51-52, 266-67, editions 2-5 (emphasis added).

29 Essay, II. xx. 3, 229-30 (emphasis added). As far as I have been able to determine, these are the only two uses of the word in Locke's corpus. 
attached to certain objects, which has an effect on the way we interact with those objects. Pleasure and pain open the door to the passions because our reflection on our sensations and their provenance gives rise to the ideas of the passions that are thenceforth associated with particular objects. Notice that here, as with the description of sensation and reflection as passive sources for knowledge, pleasure and pain are passively received. The use of 'hinge' here, then, implies a mechanism that, with the right kind of stimulus, produces an effect.

The general mechanism of a hinge has the following form: (1) the gate receives a stimulus - a push, (2) the hinge is modified as a result of the stimulus, (3) this modification causes a movement which has the effect of the door opening or closing. Applying this mechanism to pain and pleasure: (1) a human being receives a stimulus - a sensation or reflection, (2) the mind is modified as a result of this stimulus - which is to say that pain or pleasure is felt, (3) this modification causes a movement which has the effect of an idea of a passion. Here, the hinge does not itself initiate the activity, but is rather an essential passive element in the mechanism. If Locke's use of the term 'hinge' is consistent, he is suggesting that the mechanism for suspension works like this: (1) the human being receives a stimulus - a sensation or reflection, (2) the mind is modified as a result of this stimulus - in this case that a desire is suspended, (3) this modification causes a movement of the mind which leads it to consider whether 'that particular thing, which is then proposed, or desired, lie in the way to their main end'. Here, without the power to suspend, there would be no way for the mind to enter into deliberation or consideration of the thing desired. But Locke's use of 'hinge' indicates that this power, like pain and pleasure, requires an antecedent stimulus in order to perform its role in the process.

In his third and final description Locke characterizes suspension as an inlet, also in $\S 52$ :

I desire it may be well considered whether the great inlet, and exercise of all the liberty Men have, are capable of, or can be useful to them, and that 
whereon depends the turn of their actions, does not lie in this, that they can suspend their desires, and stop them from determining their wills to any action, till they have duly and fairly examin'd the good and evil of it, as far forth as the weight of the thing requires. ${ }^{30}$

Locke uses the term 'inlet' at several other points in the Essay, every time in connection with sensory experience. For example, in Book III he says:

Simple ideas, as has been shown, are only to be got by those impressions Objects themselves make on our Minds, by the proper Inlets appointed to each sort. If they are not received this way, all the Words in the World, made use of to explain, or define any of their Names, will never be able to produce in us the Idea it stands for.

Here by 'inlets' Locke means the passages through which the mind receives information that in turn produces ideas. The inlets are sense organs for they are the channels by which simple ideas travel to the mind. The presence of simple ideas in the mind is to be explained by the connection between our minds and the objects of which these ideas are representations. Now, Locke remains agnostic about how, exactly, simple ideas arise in the mind. ${ }^{32} \mathrm{He}$ does, however, clearly state that it at least seems as though ideas are produced as a result of the motion of animal spirits, whose level of agitation is a function of the stimulus of the 'operation of

30 Essay, II. xxi. 52, 267, editions 2-5 (emphasis added).

31 Essay, III. iv. 11, 424 (emphasis added). See also II. vii. 10, 132; II. ix. 14, 148; II. ix. 15, 149; II. x. 15, 149; III. iv. 11, 425; III. iv. 23, 553; III. iv. 24, 555; IV. viii. 3, 611. As far as I have been able to determine, these are the only other uses of the term across Locke's corpus.

32 For an introduction to the larger general debate over the consistency between Locke's epistemology and his atomism see, for example, John Yolton, Locke and the Compass of Human Understanding (Cambridge, 1970). David E. Soles provides a deep discussion of this question and Yolton's contribution to it in 'Locke's Empiricism and the Postulation of Unobservables', Journal of the History of Philosophy 23, (1985): 339-69. 
insensible particles on our Senses, ${ }^{33}$ Using this broad construal, we can understand the above text in this way: (1) the insensible parts of objects interact with one or several sense organs, (2) the organs are modified in a way that excites the animal spirits. The animal spirits in turn (3) produce an idea that corresponds to the particular 'inlet' of sensory input. On this mechanism, the organ itself is not the cause of the idea, but is a channel through which the information must pass for the idea to be produced. While Locke's agnosticism leaves the details of this mechanism to be debated, his use of 'inlet' to describe the sense organs indicates that howsoever the mechanism might actually work, the sense organs admit or let in but do not create the motion that is necessary to give rise to a particular idea.

If Locke's use of the term is consistent, then the role of the power to suspend in the mechanism will be much as the one described above with the 'hinge' passage: (1) the human being receives a stimulus - a sensation or reflection, (2) the mind is modified as a result of this stimulus - in this case that a presently felt desire is suspended, (3) this modification causes a movement of the mind which leads it to examine 'the good and evil of it, as far forth as the weight of the thing requires'. Again, without the power to suspend, there would be no way for the mind to enter into examination or weighing of the thing desired. But Locke's use of 'inlet' indicates that this power plays a role similar to the one playing by the sense organs in the acquisition of simple ideas: a necessary element that requires an antecedent stimulus in order to perform its role in the process.

These three descriptions of suspension as source, hinge, and inlet to liberty, then, strongly suggest that the power to suspend desire is a necessary, passive element in a process that requires a stimulus to trigger its action. This action then allows the mind to examine, consider, weigh, and deliberate about the object it desires.

33 Essay, II. viii. 13, 136. See also II. viii. 4, 133; IV. iii. 13, 545. 
But Locke sometimes gives the impression that he takes the nature the power to suspend to be in some sense active. Let us begin with $\S 47$ where the power to suspend is first introduced:

For the mind having in most cases, as is evident in Experience, a power to suspend the execution and satisfaction of any of its desires, and so all, one after another, is at liberty to consider the objects of them; examine them on all sides, and weigh them with others. In this lies the liberty Man has; (1) and from the not using of it right comes all that variety of mistakes, errors, and faults which we run into, in the conduct of our lives, and our endeavours after happiness; (2) whilst we precipitate the determination of our wills, and (3) engage too soon before due Examination. (4) To prevent this we have a power to suspend the prosecution of this or that desire...(5) during this suspension of any desire, before the will be determined to action, and the action (which follows that determination) done, we have opportunity to examine, view, and judge, of the good or evil of what we are going to do; (6) and when, upon due Examination, we have judg'd, we have done our duty, all that we can, or ought to do in pursuit of our happiness; and 'tis not a fault, but (7) a perfection of our nature to desire, will, and act according to the last result of a fair Examination. ${ }^{34}$

One might interpret the highlighted section as a statement that suspension is equated with liberty-in this, that is suspension, lies liberty. ${ }^{35}$ If liberty is supposed to confer some kind of active power upon us, then we might take this phrase to indicate that suspension is active, not passive. But the phrase in question is grammatically ambiguous. It is not clear which term mentioned in the preceding sentence is replaced by the demonstrative pronoun 'this'. There are three possibilities. Either 'this' replaces 'power to suspend', or it replaces 'liberty to consider the objects of them [the mind's desires]', or it is meant to replace both suspension and the liberty to consider the objects of desire, and thus refer to the process that

34 Essay, II. xxi. 47, 264-65, editions 2-5 (emphasis and enumeration added).

35 This is a point that Samuel Rickless makes in his review of Gideon Yaffe's Liberty worth the name: Locke on free agency, Locke Studies 1, (2001): 235-55, especially at 252. 
includes them both. I want to suggest that the third option is correct and makes the most sense of the passage as a whole. The emphasis in this passage is on our obligation to examine our desires. Here, action guided by rational deliberation is identified as the hallmark of the perfection of human nature, not the ability to suspend desire. It seems, then, that 'liberty Man has' lies in the process that includes both suspension and deliberation. The power to suspend is a necessary condition for the kind of mental activity that results in the 'liberty Man has'.

Let us consider the breakdown of the passage as represented by the numbers inserted into the text above. Locke's suggestion is this:

(1) If we fail to use liberty correctly, then we fail to conduct our lives in a way that will lead to happiness.

(2) During the time ('whilst') we fail to use liberty correctly, we hasten the determination of our wills.

(3) We thus act before fully examining the objects of desire.

(4) To prevent such unconsidered action, we have the power to suspend.

(5) During suspension, the mind has the opportunity to examine the objects of desire.(6) Properly using examination is to do 'our duty, all that we can, or ought to do, in pursuit of our happiness'.

(7) Having the will determined by rational deliberation is a perfection of our nature.

Locke does not state that suspending our desire is a perfection of our nature; it is rather a component that in the process that allows for activity that expresses the perfection of our nature. This perfection is achieved when rational deliberation has a say in what 
kinds of uneasinesses determine the will. The details of how rational deliberation can come to have such a say will be discussed below. For now, I want to suggest that if Locke wanted to insist that suspension was that in which liberty lies, he would have identified the act of suspending as sufficient for satisfying our duty in pursuit of happiness'. But here we see that suspension occupies a necessary condition role for the sufficient condition of rational deliberation to obtain.

There are three other sections in 'Of Power' where Locke uses language that is ambiguous with respect to suspension and freedom. We begin with $\S 52$, which we discussed above with a focus on Locke's use of 'inlet'. At a certain point, one may think that Locke squarely aligns this 'inlet' to liberty with the exercise of it. Recall that he writes:

I desire it may be well considered whether the great inlet, and exercise of all the liberty Men have, are capable of, or can be useful to them, and that whereon depends the turn of their actions, does not lie in this, that they can suspend their desires, and stop them from determining their wills to any action, till they have duly and fairly examin'd the good and evil of it, as far forth as the weight of the thing requires. ${ }^{36}$

One may take Locke to be squarely aligning the power to suspend and exercise of liberty in this passage. ${ }^{37}$ If we take the 'and' here to be additive, we may read the phrase as a discussion of one and the same thing that is both the 'inlet' and 'exercise' of the all the liberty. But an alternative is possible. If we take the 'and' to be connective, we may take the phrase to be a description of two separate but related things: 'the great inlet of all the liberty' and 'the exercise of all liberty'. This way, we can distinguish two lines of thought within the phrase: the introduction of two terms followed by their definitions. We may reproduce the discussion as follows:

36 Essay, II.xxi.52:267, editions 2-5.

37 For one such interpretation, see Richard Glauser 'Thinking and Willing in Locke's Theory of Human Freedom', Dialogue 42, (2003): 695-724, at 707. 
(1) There is a 'great inlet of' liberty.

(2) There is an exercise of liberty that 'Men have, are capable of, or can be useful to them, and that whereon depends the turn of their actions'.

These things can be defined as ('does not lie in this')

(1) This inlet is that 'they can suspend their desires'.

(2) That 'they can stop their desires from determining their wills to any action, till they have duly and fairly examin' $d$ the good and evil of it, as far forth as the weight of the thing requires'.

What (2) indicates is that the exercise of liberty is the process that includes both suspension and rational deliberation. Suspension is the inlet to liberty - it is the necessary condition for the deliberation to take place. 'The turn of their actions' does not depend on suspension itself, but rather what comes after suspension, namely, the result of deliberation. The suspension stops the desire from determining the will in the same way that the eight ball might stop the action of the cue ball when they come into contact. In $\$ 50$ Locke uses the expression 'standing still' to describe the result of suspending desire:

That in this state of Ignorance we short-sighted Creatures might not mistake true felicity, we are endowed with a power to suspend any particular desire, and keep it from determining the will, and engaging us in action. This is standing still, where we are not sufficiently assured of the way: Examination is consulting a guide. The determination of the will upon enquiry is following the direction of that Guide: And he that has a power to act, or not to act according as such determination directs, is a free Agent. ${ }^{38}$

38 Essay, II. xxi. 50, 266, editions 2-5 (emphasis added). 
This 'standing still' may be taken to imply that the power to suspend is active - it has the power to interrupt an action in order to stand still and evaluate the situation at hand. But notice that here, as in the sections discussed above, Locke continues to align freedom (he that acts as a 'free Agent') with the power to act according to the rational determination ('determination... following the direction of that Guide') of the mind. Free agency is linked to action following rational deliberation and not following suspension alone. This interpretation is supported by Locke's assertion in $\S 67$ :

And he that is at liberty to ramble in perfect darkness, what is his liberty better than if he were driven up and down, as a bubble by the force of the wind? The being acted by a blind impulse from without, or from within, is little odds. The first therefore and great use of Liberty, is to hinder blind Precipitancy; the principal exercise of Freedom is to stand still, open the eyes, look about, and take a view of the consequence of what we are going to do, as much as the weight of the matter requires. 39

Here, Locke explicitly ties 'the principal exercise of freedom' to the process of standing still (suspending desire) and rationally deliberating about the right thing to do in a given situation. This passage shows the connection between the suspension and the power of thought. ${ }^{40}$ I suggest that here, as above, the role of suspension ought to be considered as a power that interrupts a desire in the same way that billiard balls may interrupt each other's motion.

39 Essay, II. xxi. 67, 279, editions 2-5 (emphasis added). Note that Locke's use of 'is little odds' should be understood as 'it makes no difference' (see OED definition (c) of 'odds'). The idea is that it makes little difference if we are blindly determined by forces from without or from within; the unwelcome result is the same.

40 I agree here with Glauser's interpretation of this passage. See Glauser, 'Locke's Theory', 707. But while Glauser goes on to argue that Locke wavers between two positions where he alternately takes suspension as a necessary condition for freedom and as assimilated to freedom, I will argue that the latter view is not present in Locke's discussion. 
I have argued that Locke's descriptions of suspension strongly suggest that he takes the power to suspend to be passive. Nor is there any suggestion that suspension is the product of an undetermined volition. I have also suggested that where it seems that Locke is assimilating suspension and freedom, he is always aligns the process of rational deliberation, of which the power to suspend is a necessary element, with action that proceeds from a 'free Agent'. Suspension is the power that allows us to get to the state of 'standing still' in order to examine our desires, but it needs an input in order to trigger this effect. But if suspension is neither an active power nor the effect of an undetermined volition, we need to look elsewhere for clues about its nature and its connection to liberty. What Locke says about judgement in the context of his discussion of the Molyneux problem turns out to be instructive in this regard.

\section{Perceiving-with-judgement}

Locke notes that it is often the case that, without our notice, the ideas we receive by sensation are altered by judgement. ${ }^{41}$ To use Locke's example, suppose we see a globe in the corner of the room. What we really perceive is a flat surface that is a portion of the globe. Through experience we come to learn that the flat surface is part of a globe. Our minds correct for our, in a sense incomplete, perception. While our actual perception does not change, once we realize that the flat surface is part of the globe, in future instances the perception of the flat surface is joined by other ideas that allow us to identify the globe. Our minds do not create a new idea of the globe in these future instances, but through experience our mind learns to 'correct' the perception. This observation about judgement is the lead-in to the Molyneux problem. ${ }^{42}$ Molyneux writes to Locke with a thought experiment: suppose there is a man who has been blind from birth. He has been

\footnotetext{
41 Essay, II. ix. 8, 145.

42 Essay, II. ix. 8, 145-46, editions 2-5.
} 
taught to identify a globe and a cube by touch alone. The question is: could this man, if suddenly able to see, distinguish between a cube and a globe by sight alone? Molyneux suggests that he could not, and Locke agrees. While Locke does not explicitly connect this conclusion to the preceding globe discussion, we can see that just as the newly sighted man needs a visual perception and additional information before being able to identify a globe and a cube by sight, we need to understand that the perceived flat portion of the convex body is actually a convex body before our judgement prompts the mind to fill in what is missing in the perception. Let us call this informed perceiving 'perceiving-with-judgement'. ${ }^{43}$

Before long the mind corrects for the incomplete perception by habit. And so, Locke writes, we should not be surprised that our minds often change the idea of sensation into one of judgement without our notice. ${ }^{44}$ The question to turn to now is how the mind is able to call up the corrected perception when it is immediately experiencing the, as it were, incomplete perception. Locke turns to this topic in the very next section 'Of Retention'. There he considers the two ways ideas are stored in the mind after they are perceived. First, by contemplation, or keeping them in view for a prolonged period of time, and second, by the power to 'revive again in our Minds those Ideas, which after imprinting have disappeared, or have been as it were laid aside out of Sight'. This is memory. ${ }^{45}$

Locke states that the human mind cannot handle the consideration of many ideas at once. So we have a repository in which ideas are stored for later use. But Locke has an unusual conception of memory. On his view, ideas are nothing more than

43 For an elegant discussion of how the globe discussion fits into Locke's larger view of ideas and some problems it raises, see Martha Bolton, 'The Taxonomy of Ideas in Locke's Essay', in The Cambridge Companion to Locke's Essay concerning Human Understanding, ed. Lex Newman (Cambridge, 2007), 67-100, esp. 80-83, 99-100.

\footnotetext{
44 Locke, Essay, II.ix.10:147.

45

Locke, Essay, II.x.1:149
} 
actual perceptions of the mind, which means that when not perceived they 'cease to be any thing'. When Locke talks about a repository of ideas he means 'that the Mind has a Power, in many cases, to revive Perceptions, which it once had, with this additional Perception annexed to them, that it has had them before'. ${ }^{46}$ Attention aids in the fixing of ideas in the memory. ${ }^{47}$

Now, according to Locke, while perception is passive, the mind is 'oftentimes more than barely passive' when it experiences the 'secondary perception' of reviewing ideas that have been implanted in memory. ${ }^{48}$ This is because the ideas that were previously perceived can sometimes be called up at the command of the will. This ability to call forth previously perceived ideas is of critical importance. Without memory, all of our other faculties would be useless because we would not be able to proceed beyond presently perceived objects. ${ }^{49}$ Paying attention and repeating perceptions helps to fix them in our memory. The more fixed they are, the more readily recalled when needed. I suggest that the faculty of retention is connected to perceiving-with-judgement. When we first see the globe when its full shape is occluded, we do not perceive it as spherical. Only after investigating the globe do we learn that it is. We attend to the idea of the globe and affix it in our memory. Thereafter when we have a similar perception under similar conditions, we recall our previous experience and our mind makes the necessary correction. But it is only attention to the idea and the experience of the globe as spherical that allows us to thenceforth perceive-with-judgement.

To return to the topic of liberty, let us consider perceiving-with-judgement with respect to moral evaluations.

46 Essay, II. x. 2, 149.

47

Essay, II. x. 3, 150. See also II. xix. 1, 227.

48 Essay, II. x. 7, 152. Locke's use of 'barely' here is different from our common use. The OED definition (archaic) is: merely, simply, only.

49 Essay, II. x. 8, 153. 
Though Locke's examples in his discussion of perceiving-withjudgement have to do with perceptions of geometrical objects, we can extend this ability to moral judgements. Locke endorses this kind of extension when he explicitly links errors in perceptual judgement to errors in judgements about future pains and pleasures. $^{50}$

Locke notes that it is more important to acquire clear ideas with respect to moral relations than in any other part of knowledge. ${ }^{51}$ He states that good and evil are nothing more than pleasure and pain or those things that produce pleasure or pain in us. Connecting pain and pleasure to moral rules, we get the following statement:

Morally Good and Evil...is only the Conformity or Disagreement of our voluntary Actions to some law...which Good and Evil, Pleasure or Pain, attending on our observance, or breach of the Law, by the Decree of the Law-makers, is that we call Reward and Punishment. ${ }^{52}$

Locke identifies three sets of moral laws as the sources of reward and punishment - divine, civil, and opinion or reputation. All three entail reward and punishment for, he says, it would be in vain to set up rules for the free actions of human beings without having the threat of punishment or the promise of reward as enticement to follow the laws. ${ }^{53}$ As we have seen, for Locke the desire for things that promise pleasure and the avoidance of those that cause pain - uneasinesses - are the only motives for action. It is easy to

50

Essay, II. xxi. 63, 275.

51 Essay, II. xxviii. 4, 351. Locke is explicit that our evaluations of moral good and evil are only in reference to pleasure and pain (II. xx. 2, 229; II. xxi. 42, 258-59, editions 2-5; II. xxviii. 5, 351). But he also suggests that we weigh different pleasures differently, and that we distinguish between present goods, which are always equivalent to real goods (II. xxi. 58, 272, editions 2-5) and remote goods (see II. xxi. 56, 270, editions 2-5). More on this below.

52 Essay, II. xxviii. 5, 351.

53 Essay, II. xxviii. 6, 351. 
see the consequences of violating civil law, for civil authorities have the power to remove life, liberty, and goods. ${ }^{54}$ When the laws of opinion are broken the transgressor is disgraced and shunned by his peers. ${ }^{55}$ Understanding the consequences of disobedience to divine law is less straightforward.

Consider a civil rule like 'it is wrong to steal'. Early in life we come to perceive stealing as wrong. We are warned of the pain of punishment for this act, perhaps we see it enacted, and our perception of stealing is annexed thereafter to the idea of pain. Similarly, within a community a particular moral rule like 'shoes ought to be removed before entering a home' becomes engrained such that removing one's shoes before entering a home is perceived as good. This perception might be connected with ideas surrounding respect, and perhaps past examples of damaged reputations befalling those who failed to abide by this community rule.

It is less clear how to understand the force of the divine law if reward and punishment are given in the next life. Locke states that the divine law is promulgated to man 'by the light of Nature, or the voice of Revelation'. ${ }^{56}$ Given that the voice of revelation is scarce enough to prevent its being a candidate to guide everyday activity, we must wonder what exactly Locke means by the light of nature in this context. Locke defines the light of nature as "nothing else but the Evidence of the Truth of any Proposition'. ${ }^{57}$ When it comes to understanding the divine law, the light of nature seems to inform us of the relative pains and pleasures associated with certain ideas.

54 Essay, II. xxviii. 9, 352-53.

55 Essay, II. xxviii. 10, 353, editions 2-5.

56 Essay, II. xxviii. 8, 352, editions 2-5.

57 Essay, IV. xix. 13, 703. See also I .iv. 9, 89; I. iii. 6, 69; III. ix. 23, 490; IV. xviii. 8, 694-95; IV. xix. 13-15, 703-5; IV. xvii. 24:687-88. 
Locke states that 'the infinite wise author of our being' joined the perception of delight to certain thoughts and sensations in order that we are moved to pursue certain actions and inquiries. ${ }^{58}$ Further, 'it is wisely ordered by Nature' that pain accompanies the reception of certain ideas so that we are moved to avoid harmful things. ${ }^{59}$ Locke characterizes the divine law as a set of rules of conduct, which he takes to be discoverable and 'the only true touchstone of moral Rectitude ${ }^{60}$ Given that it is a law of nature that pleasure will lead us to the good, we know that pleasure will be involved in our search for the contents of the divine law. ${ }^{61}$

The trouble is that not all things that promise pleasure are, in fact, morally good or, to put it in Locke's terms, not all pleasurable things will lead to true and solid happiness. The promise of pleasure is what motivates the act of adultery but this is surely a violation of divine law. However it seems that with an attentive investigation of the idea of adultery, the idea of pain will come to be associated with the idea. Like the annexing of 'pain, thus evil' to stealing through attention, instruction, or example, the same effect will follow from similar attention to the idea of adultery. Perhaps the idea comes to be joined to pain because we see that the promised pleasure is ephemeral, does not outweigh the eventual pain, etc. We pay attention to ideas, we learn through education and experience, and we come to regard our perceptions in different ways - we perceive-with-judgement. We thus drive a wedge between two kinds of pleasurable perceptions - those ultimately judged to be connected to 'true and solid' happiness and those judged to be merely present goods. And if our judgements are in

Essay, II. vii. 3, 129.

59

Essay, II. x. 3, 150. See also II. xxi. 34, 252, editions 2-5.

60

Essay, II. xxviii. 8, 352, editions 2-5.

61 For an insightful discussion of the divine law in Locke, see Nicholas Wolterstorff, 'Locke's Philosophy of Religion', in The Cambridge Companion to Locke, ed. Vere Chappell (Cambridge, 1994), 172-98. 
earnest 'we have done our duty, all that we can, or ought to do, in pursuit of our happiness'. 62

Let us now connect perceiving-with-judgement to suspension of desire. Consider two people, one attentive and one inattentive, who encounter wine for the first time. Both find it pleasurable, both overindulge, and both feel ill the following day. The attentive person thinks about the cause of her feeling ill and figures out that it was too much wine the night before. The next time she desires wine, her memory of the pain associated with her overindulgence will cause her to perceive with a certain judgement. Her previous experience informs her current one, and her desire for the object is suspended. The affective component of her perceiving-withjudgement serves as a stimulus to counteract the anticipated pleasure in the present good. Once the pain-avoid response associated with the memory of the wine interrupts the initial pleasure-uneasiness response of the perceived good, a space is opened for another uneasiness to determine the will. Recall that Locke insists on the connection between acting as a free agent and rational deliberation. It seems that the ideal uneasiness to determine our will once the mundane goods that lead to imaginary happiness are dispatched is the uneasiness for rational deliberation. If we are uneasy for a full understanding of the objects that affect us in our environment, once our desire for the mundane good is suspended our mind is free to be determined by the want of an examination of the object in question. After a sincere examination of an object, our will is determined by the last result of the investigation. Thereafter, the result of this examination comes to be accessible by the memory, thus building up the content of the affective component annexed to the object in the mind. The next time the object is contemplated, the mind will have an even stronger competing negative affective component to counteract the uneasiness for the wine. The competing negative affective content may eventually be enough to eliminate the uneasiness for the wine altogether. By contrast, the inattentive person has no such

62 Essay, II. xxi. 47, 264, editions 2-5. 
guarantee of suspension when she next desires wine. If she has not thought about the experience and not judged the wine to be the culprit of the illness, no counterbalancing painful memory will be triggered by her perception of the wine. This means that the desire will not be suspended by the competing affective component and her uneasiness for the wine will determine her volition.

It might be objected that judgements made about the true shape of an object and moral judgements about present and remote goods and evils are too disanalogous for the same mechanism to be at work in both cases. For, one might say, consider the following two cases: first, take the experience of a stick appearing bent in water. We might be curious about this phenomenon and investigate its cause. Once we understand the process of refraction of light in water we understand why the stick appears bent. This knowledge becomes part of our store of remembered ideas. When we next perceive a similar phenomenon, say when canoeing and we notice that our oar appears bent as it dips into the lake, we remember the conclusion of our previous investigation and while we perceive that the oar is bent, we understand that it is not.

Second, take the experience of perceiving an opportunity to achieve honour. Suppose we desire the honour, but have reason to doubt that it is a true good (because of warnings from trusted advisers, witnessing others attempt to secure honour who have suffered painful consequences, etc.). We decide to examine its worth relative to other desired pursuits and eventually decide that it is not a true good worth pursuing. The outcome of this deliberation becomes part of our store of ideas. When we are next tempted by a similar pursuit, we might still have desire for it, but we will remember the pain that the previous judgement associated with the object, and this pain will outweigh the current desire. Here one might point out the following disanalogy: because pain and pleasure play a role in our moral evaluations they are subjective in a way that, importantly, the evaluation about whether the oar in the water is actually bent is not. For affective responses play no role in whether one accepts the reasoning for why a stick appears bent in water. If one objected to the notion that the stick only appears 
bent, the reasoning could be presented as conclusive evidence for changing one's mind. We might think that the case of whether honour ought to be pursued is not an objective fact of the matter and so no such reasoning can be presented. Let us evaluate this objection.

To begin, it is important to remember that uneasiness motivates all actions for Locke, not just those categorized as morally good or evil. ${ }^{63}$ So when the canoeist notices that her oar appears bent, it is uneasiness that motivates her examination of the circumstances under which such a perception occurs. The discomfort of accepting the perception without further thought motivates the investigation. If the canoeist is earnest in her investigation, her uneasiness will not be dispelled until she arrives at an explanation for the phenomenon. For Locke, it is the very same operation with what we take to be more morally charged evaluations. The desire for honour might not be felt without reservation - and the examination about the worthiness of the pursuit is launched in order to address all aspects of the uneasiness associated with the idea. But does this mean that the role of pain and pleasure in the case of learning about refraction of light in water is different from that in the case of evaluating the pursuit of honour?

For Locke the answer must be no. This is important because for any evaluations of moral good and evil there must be a distinction between the goods that will lead to 'true and solid happiness' and those that lead merely to 'imaginary' happiness. ${ }^{64}$ If this weren't so there would be no way to distinguish between the virtuous and the vicious. This means that the goods that lead to true and stable happiness are the same for everyone, no matter which present goods seem pleasurable to us. Without this objective measure there could be no morality. ${ }^{65}$ On Locke's account the mechanism of

63

Essay, II. i. 4, 105-6; II. vii. 2, 128.

64

See $\S 52$ for these distinctions.

65 Locke would surely disapprove of the person whose curiosity to learn more about their environment is never piqued by their perceptions. While he notes that due to their lot 
assent will be the same in all matters of judgement-moral or otherwise. When the mind perceives the agreement of ideas ('whether immediately, or by the Assistance of Reason') it cannot refuse assent. Further 'what upon full Examination I find the most probable, I cannot deny my Assent to'. We can no more refuse assent to the final result of our examination than we can refuse to perceive what is in front of us. ${ }^{66}$ This holds true whether the item under consideration is the refraction of light or the relative goodness of honour.

But it is not enough to state that there are discoverable goods that lead to true and solid happiness. Locke must explain how they are to be discovered. Pleasure and pain must be those things that guide our investigation of the true good. ${ }^{67}$ As noted above, Locke understands the role of pain and pleasure, as joined by God to certain objects, as indicators of what will or will not ultimately lead to happiness. For our part, our nature determines that we act based on our perceptions of goods we take to be pleasurable. Thus, by the mere fact that we exist in the world we will be in a position to acquire some measure of happiness as we come to know the pleasure and pain of certain objects and by pursuing the things for which we are desirous. But to attain true and solid happiness, it does not seem sufficient to blindly pursue our uneasinesses. Some of our uneasinesses will naturally transform as a function of our increasing knowledge about the effects certain objects have on us (think, for instance, of the effect of one serious allergic reaction). But we will have to work to increase of knowledge of other more subtle goods. The greater our knowledge of the kinds of things

in life many people have neither time nor means to examine proofs or conduct enquiries, he nevertheless stresses that no one is too busy to contemplate his own soul and everyone is equally equipped to do so. See Essay, IV. xx. 1, 706; IV. xx. 3, 708.

66 Essay, IV. xx. 16, 717.

${ }^{67}$ In an earlier work Locke defends the view that there is an objective law of nature discoverable through sense perception, with emphasis on pain and pleasure. See John Locke, Essays on the Law of Nature, ed. \& trans. Wolfgang von Leyden (Oxford, 1954), 155. 
with which we interact, the more our uneasinesses will be in line with our pursuit of true happiness. While education, first-hand experience, and/or example may be enough to produce the counterbalancing memory to trigger the suspension of a present desire, in many cases it will take serious analysis and examination of an object while our desire for it is suspended, to ultimately change our affective response in relation to it.

This account preserves Locke's insistence that it is only uneasiness that can motivate volition. It is not our remembered cognitive content about a present good that stops our pursuit of it, but rather the affective component of remembered content that counterbalances the felt desire. The ultimate goal is for the examination to have the further consequence of changing our uneasiness for goods that do not help us attain true happiness. Beyond the power of the mind to change the relative strength of desire for an object, if we are attentive and embed our ideas deep into our memories so that our 'perceived-with-judgement' ideas are as vivid as possible when they are recalled at the appropriate moments, it is possible that we could eventually suspend our desire for certain present goods without noticing. This would amount to diminishing or even extinguishing certain uneasinesses.

Suspension, then, is anything but the result of an undetermined volition. It is something that happens to us as a result of contradictory information: the promise of pleasure from the present perception combined with uncertainty about the good's relation to true happiness from remembered information about the good. The power to suspend is a fact about our motivational psychology, that competing or contrary desires can interrupt the route to action. In virtue of our experiencing the world, our understanding of things is modified to account for our experiences of them. Our minds are thus altered so that they have the disposition to recall such ideas when relevant to some presently considered action. The passive power to suspend desire is thus the power of the mind to undergo this change with respect to which ideas it recalls and when, in the service of being guided towards the true, rather than imaginary, happiness. This is an event that we 
passively experience or 'daily experiment' within ourselves. ${ }^{68}$ This event thus opens the mind to enter into a deliberation about whether the good in question contributes to true happiness.

\section{The End and Use of Liberty}

A consequence of the interpretation offered above is that Locke's view of human liberty falls under the category of a kind of 'indirect intellectualism'. According to intellectualism, to be virtuous one only needs knowledge. Error and sin result from ignorance alone. For Locke, if we fail to attend to our ideas, we lack the knowledge that allows us to perceive-with-judgement. And it is perceivingwithout-judgement that leads to vice. One can only be faulted for error and sin due to lack of experience and contemplation because adequate contemplation results in altered uneasiness. The mechanism is indirect because while knowledge does not directly determine volition, it does directly influence uneasiness, which in turn determines volition. Error and vice are caused by the ignorance which allows unconsidered promises of pleasure to motivate action. This understanding brings Locke's view very near to the moral psychology outlined by Hobbes in Leviathan and in even more detail in his polemic with Bramhall. ${ }^{69}$ Throughout his writings, Hobbes gives the impression that people take their actions to be free only because they are ignorant of the causes that, in fact, necessitate all of their actions. ${ }^{70}$ The determining causes depend on our past experiences and the appetites and fears that

68

Essay, II. xxi. 47, 263, editions 2-5. Locke uses 'experiment' to mean 'undergo', the primary definition in his time. The OED, the first definition (obsolete), of experiment: to have experience of; to experience; to feel. He uses the term in a similar way to describe our passive awareness of our ideas (II. xxiii. 15, 305).

69 Collected in Hobbes and Bramhall on Liberty and Necessity, ed. Vere Chappell (Cambridge, 1999).

70 This is also Spinoza's view. For a lovely discussion of the connection between Hobbes and Spinoza on this point see Leopold Damrosch, Jr., 'Hobbes as Reformation Theologian: Implications of the Free-Will Controversy', Journal of the History of Ideas 40, (1979): 339-52, at 351-52. 
have come to be associated with certain outcomes. ${ }^{71}$ To use weakness of will as an explanation for an action would be evidence that one does not fully understand the causes at work in her psychology. For both Hobbes and Locke there is an enormously large role to be played by external factors in our explanations of behaviour. The things we have been exposed to and the lessons we have been taught all contribute to the causes that determine our action. The more knowledge we have of the pleasurable and painful effects of action, the more our future actions will tend towards pleasure and away from pain. There is, however, an important distinction between their views. For Hobbes, it does not seem that there is any use for freedom beyond the ability to act according to our desire. Locke, however, states that there is an 'end and use of our Liberty' and thus implies that there is a correct use to which this power ought to be put. ${ }^{72}$ And what is this end and use?

When, upon due Examination, we have judg'd, we have done our duty, all that we can, or ought to do, in pursuit of our happiness; and 'tis not a fault but a perfection of our nature to desire, will, and act according to the last result of a fair Examination. This is so far from being a restraint or diminution of Freedom, that it is the very improvement and benefit of it; 'tis not an Abridgment, 'tis the end and use of our Liberty. ${ }^{73}$

Locke states that a human being, by its nature as an intelligent creature, is "put under a necessity...to be determined in willing by

71 This kind of remark occurs throughout the correspondence with Bramhall. For a clear statement see Thomas Hobbes, Leviathan ed. Noel Malcolm (3 vols., Oxford, 2012), I. vi. 28-29, ii, 90-94.

72 Essay, II. xxi. 31, 255, first edition, II. xxi. 49, 265, editions 2-5. See also II. xxi. $30,251-55$, first edition, II. xxi. 48:264-65, editions $2-5$. There is disagreement in the literature about whether being determined by the true good is essential to Locke's view of freedom. For the view that it is, see Yaffe, Liberty Worth The Name, passim. For the view that it isn't, see Rickless's review of Yaffe's book, cited above.

73 Essay, II. xxi. 47-48, 263-64, editions 2-5. 
his own Thought and Judgement, what is best for him to do: else he would be under the determination of some other than himself, which is want of Liberty'. ${ }^{74}$ The end and use of liberty is the exercise of this capacity for rational thought and judgement in order to act in ways that are, as far as possible, in accordance with the pursuit of happiness. Above we looked at Locke's description of a drunk who, when sober, recognizes and approves of the greater good of sobriety. If Locke said no more about this duty to act in accordance with our best understanding of our happiness, it would be impossible to see how the drunk is failing to meet this obligation. For, though the drunk sees that it would be better for him to be sober, he does not yet have the necessary understanding of this fact that, according to Locke, would contribute enough of a counterbalancing affective response to render the desire for alcohol impotent. The drunk thus acts according to his current understanding of his happiness, such as it is. But several sections later Locke states:

The inclination, and tendency of their [intellectual beings] nature to happiness is an obligation, and motive to them, to take care not to mistake, or miss it; and so necessarily puts them upon caution, deliberation, and wariness, in the direction of their particular actions, which are the means to obtain it. Whatever necessity determines to the pursuit of real Bliss, the same necessity, with the same force establishes suspence, deliberation, and scrutiny of each successive desire. ${ }^{75}$

Though he does not use the term 'uneasiness', it is clear that Locke is suggesting that there is an uneasiness for 'true Bliss' that is itself necessary and that in turn acts upon the power to suspend with necessity. To act exclusively in accordance with 'true Bliss' is to act in perfect accordance with our nature as intellectual beings. It is clear that for Locke, such perfect action would be wholly determined by rational deliberation. So, when the drunk acts, he

\footnotetext{
74 Essay, II. xxi. 48, 264, editions 2-5.

75 Essay, II. xxi. 52, 267, editions 2-5. See also IV. xvii. 24, 688.
} 
acts according to his present uneasiness. According to the first edition account of liberty, the drunk acts freely because his action is determined by his preference. According to the second edition account, he does not act freely because his preference is not the result of rational deliberation. This is a failure to use the power of liberty for its proper end. While the drunk can say that sobriety is a greater good than drunkenness, he does not yet feel it. This indicates that his examination is lacking. On Locke's view, it seems that with enough attention and contemplation, this would change. ${ }^{76}$ The question that remains is: can such a change be self-initiated? In other words, do intellectual beings possess a true active power?

At the very end of 'Of Power' Locke gives the most concise statement of an active power. He says that 'to be able to bring into view Ideas out of one's sight, at one's own choice, and to compare which of them one thinks fit, this is an Active Power'. ${ }^{77}$ Once desire is suspended, the mind is able to enter into contemplation and actively call forth ideas for comparison and evaluation in order to assess the overall value of the good in question. Using this active power is what allows rational beings to exercise liberty-the liberty of having their volitions determined by preferences that result from rational consideration. The more we come to perceive present goods with the judgement that they are not worthy of pursuit, the more it is freed from mundane uneasinesses. As a consequence, the mind is afforded the opportunity of being affected by the uneasiness for remote goods. For, it is only with the extinction of eliminable desires that the uneasinesses generated by remote goods will be determining. ${ }^{78}$ The mind is then free to

76 On this point I agree with Vere Chappell. See his 'Power in Locke's Essay', in The Cambridge Companion to Locke's Essay, 130-56, at 152-54.

77 Essay, II. xxi. 72, 286, editions 2-5. It must be noted, however, that earlier in the chapter Locke suggests that active powers may really only belong to 'God and Spirits' (see $\S 2)$.

78 Locke, Essay, II. xxi. 45, 261-62, editions 2-5. 
contemplate remote goods, make further judgements, and continue its training. We can use this understanding of the connection between suspension, deliberation, and liberty to defuse one final objection to this interpretation based on an addition to the fifth edition of the Essay.

\section{Choosing the Remote Good}

The passage in question appears in $\$ 56$. According to Chappell, its inclusion in the last edition of the Essay published in Locke's lifetime gives us reason to think that Limborch was successful in his attempt to convince Locke that a conception of liberty is meaningless without undetermined volitions. Limborch was particularly worried about attributing praise and blame in a system where no weakness of will is possible. Chappell states that the following passage lends support to the view that the power to suspend is active and undetermined:

In most cases a Man is not at Liberty to forbear the act of volition; he must exert an act of his will, whereby the action proposed, is made to exist, or not to exist. But yet there is a case wherein a Man is at Liberty in respect of willing, and that is the chusing of a remote Good as an end to be pursued. Here a Man may suspend the act of his choice from being determined for or against the thing proposed, till he has examined, whether it be really of a nature in it self and consequences to make him happy or no. ${ }^{79}$

It is clear that in most cases our volitions are determined without our notice. The majority of our lives are taken up by actions intended to alleviate mundane uneasinesses - hunger, thirst, etc. Locke writes that we also often acquire 'irregular desires' like those for 'Honour, Power, or Riches'. These desires also dominate much of our attention so that 'very little part of our life...[is] free to the attraction of remoter absent good'. The only prescription for avoiding a life taken up entirely by the effort to dispatch routine

Essay, II. xxi. 56, 270, fifth edition (emphasis added). Chappell discusses this passage in 'Locke on the Liberty of the Will', 118. I take the present discussion to also apply to $\S 25$, which also received a similar 'in most cases' in the fifth edition. 
desires is the repeated contemplation of the remote absent good. Such contemplation will bring the remote good nearer to our minds and increase our natural uneasiness for it 'and so according to its greatness, and pressure, comes in its turn to determine the will'. ${ }^{80}$

But how to do this? In light of all the passages discussed above, it would be quite inconsistent of Locke to suggest here that we could pursue the remote good without it being our present greatest desire. But, if we understand the suspension as a result of perceiving-with-judgement, we can make sense of this passage. Without attending to our ideas and the experiences we have of the objects with which we interact, our volitions are determined by the most pressing uneasiness regardless of their ultimate value. But, with such attention, our memory becomes stocked with ideas that have been annexed by pain and pleasure as a result of experience and judgement. When we encounter previously desired goods that we now know lead to imaginary happiness, the mind will recall the result of previous encounters with that object. The desire is thus suspended. This is how we have 'liberty in respect of willing' - once experience informs us that certain goods promise both pleasure and pain our uneasiness for the good is no longer straightforwardly determining. The liberty of the mind that is made possible by the suspension of the desire allows for examination and analysis of the good, and by this process of reasoning we can make determinations about the relative value of the good. This in turn alters, in a sense, the way we perceive. In many cases we are not able to avoid being determined by hunger or fatigue; but in some cases suspension allows us to avoid being determined by things that we have reason to suspect are less than worthy, thus allowing us to examine them fully. If we make the resolution to always be attentive to the cognitive and affective content of our ideas, we thus we use liberty for the end to which it is designed. ${ }^{81}$

80

Essay, II. xxi. 45, 261-62, editions 2-5.

81

This is the kind of mechanism at work in $\$ 53$ where Locke concludes: 'Nor let any one say, he cannot govern his Passions, nor hinder them from breaking out, and carrying him into action; for what he can do before a Prince, or a great Man, he can do alone, or in 
This interpretation fits well with the discussion that follows $\S 56$. Over the course of the next sixteen sections Locke canvasses all the reasons why we might be uneasy for lesser things instead of greater things. Nowhere does he suggest the problem is a fault with our capacity to will one thing over another. The blame is always located squarely in the shortcomings of understanding. An insufficient childhood education, a natural dislike of contemplation, or limited worldly experience may negatively affect the extent to which our uneasiness for 'true Bliss' determines our behaviour. But the uneasiness for true happiness is hardwired into human nature, and thus it is equally possible for everyone, with enough experience, to arrive at a state where the loftiest uneasiness will determine the will. ${ }^{82}$ At bottom, there is great optimism in this view. With enough experimentation, observation, and contemplation, we can behave in the way that is most in accordance with the highest perfection of our rational nature. The only weakness possible is the lack of knowledge - the remedy to which is equally accessible to all.

\section{Université du Québec à Montréal ${ }^{83}$}

the presence of God, if he will'. While at first glance it looks like Locke is baldly stating that we have the power to freely will to govern our passions, the text that precedes this conclusion indicates that governing the passions is dependent on our making a resolution to align 'the relish of our Minds' with 'the true intrinsic good'. This is done by experiencing things and considering their worth, which in turn modifies the degree of our uneasiness. While we cannot will to change the uneasinesses associated with our passions, we can resolve to analyse them.

82 While not locating sin and error in the weakness of will, this interpretation nevertheless offers a response to Molyneux's worry about connecting sin and error to ignorance alone (see n. 10 above). According to Locke, our desires are suspended as a function of experience, and it is in principle possible for everyone to develop the uneasiness for deliberation. This, in turn, will enable the natural uneasiness for the remote good to become determining.

${ }^{83}$ I thank Donald Rutherford, Shelley Weinberg and an anonymous referee for this journal for helpful and thoughtful comments that contributed greatly to the final version of this work. I also thank the audiences who heard early versions of this paper at the Early Modern Circle Workshop at CalTech (2011), the Central APA (2012), and the Locke Workshop at St. Andrews (2012). This research was conducted while I was an SSHRC postdoctoral fellow at the University of California, San Diego. I value their support. 